NGTT Deel 54, Nommers 3 \& 4, September en Desember 2013

Wessels, Francois

Stellenbosch University

\title{
Did Luther get it altogether wrong? Luther's interpretation of the function of the Mosaic law in Galatians
}

\section{ABSTRACT}

While a student at the University of Stellenbosch in the 1970s, I struggled through Herman Ridderbos' 600 page Paulus - Ontwerp van zijn Theologie (Paul - Design of his Theology). Halfway through the book a classmate, Dirkie Smit, came to my rescue by allowing me to have a look at some of his handwritten notes. These notes - and his verbal explanation, delivered in one late-night session - gave me the key to understand Ridderbos' concerns. Suddenly I understood why Ridderbos used his first chapter to explain (and debunk most of) the different nineteenth- and twentieth-century schools of Pauline interpretation. I understood why the second chapter was one on Grondstructuren (foundations) and why the third chapter - in which Ridderbos really started to deal with the material from Paul's epistles - was about "In leven in de zonde" (In living in sin). Ridderbos' book introduced me to Paul and prompted me to reflect on the apostle in a way that eventually led me to do my postgraduate work in New Testament Studies.

For this and for much more I am grateful to Dirkie and delighted to offer these reflections on Paul as part of this volume in Dirkie's honour. I have always thought Ridderbos' interpretation of Paul (and why he interpreted him in the way he did) was the one which I understood reasonably well. This is not to say that I, in later years, did not on occasion wonder whether and to what degree the Ridderbos interpretation of Paul that I knew was the pure Paul of Ridderbos and not the Smit reading of the Paul of Ridderbos. This did not lessen my appreciation of Smit's contribution to my thinking about these matters. It was his thoughts on the process of reading and interpretation - for example in his 2006 work Neem, lees! (Take, Read!) - that prompted me to reflect on Smit's influence on my reading of Ridderbos' Paul.

This brings me to the subject of this essay: the influence of reading strategies on the interpretation of texts. In recent Pauline studies the so-called Lutheran reading of Paul has been fiercely disputed. In my opinion, it would be fair to say that, despite staunch defenders, the tide is turning against the Lutheran reading. The question I turn to in this article is whether this tendency is justified, in other words: Was Luther's interpretation a valid one?

\section{A Lutheran ReAding and neW PeRspectives on Paul}

Before I proceed: For the sake of clarity, a few remarks on how certain key phrases are used in this article.

First, the phrases "a Lutheran reading of Paul" and "a New Perspective on Paul" describe relative opposites. The latter is really a new perspective on Paul as he was understood in mainline Protestant tradition - which, in turn, was fundamentally shaped by Luther's interpretation of Paul. Thus, the terms "a Lutheran reading of Paul" and "the Old Perspective" are very close to synonymous. It is also important to remember that the socalled New Perspective is not one, 
NGTT: Oopbron - http://ngtt.journals.ac.za

clearly defined concept. Many scholars have rightly pointed out that one should rather speak of this phenomenon in the plural - "New Perspectives on Paul" - since, in the words of Wax (2006:3),

it could hardly be considered a "movement" in any cohesive manner. It continued to be a loose batch of similar opinions regarding first century Judaism and how theological concepts like salvation and justification would have been understood by those in the first century.

Second, the "Lutheran" reading is first and foremost Martin Luther's interpretation of Paul, but it is also more than that: It is also the dominant reading found in the Lutheran tradition - which subsequently became very much the dominant reading in most Protestant churches. It is wise to distinguish between these two meanings. Douglas Campbell makes the point that Luther's own interpretation of the concept of salvation in Paul's letters is more nuanced than that of the followers of the Lutheran tradition. He (Campbell 2009:265) remarks that "Paul at times speaks unequivocally of an intimate, participatory, and trans formational soteriology", which was at odds with his normal, "contractual" way of understanding the process of salvation. ${ }^{1}$ Yet, for the most part, Campbell admits, Paul's way of speaking is not so much different from the way his followers later spoke about salvation. This distinction will be recognised in this article by speaking of "Luther's" and the "Lutheran (interpretation)" respectively, although for the most part there may not be a crucial difference between the two.

But why was it necessary to correct the Lutheran reading of Paul? A helpful way to answer this may be to describe three focal points in the discussions over the last two decades. Scholars claimed that they acquired new perspectives in three areas. This led them to discard, fully or partially, the traditional Lutheran reading.

\section{A re-appraisal of first-century Judaism}

In 1977, the New Testament scholar E. P. Sanders published his Paul and Palestinian Judaism. In this book Sanders argued that the Judaism of Paul's time was not a system by which the Jews earned God's grace by their observance of the Law of Moses. With reference to Jewish literature, Sanders showed that Jews in the time of Paul assumed that they were chosen by God to be his people. Jews did not think they had to earn God's acceptance as a result of keeping Torah. On the contrary, they assumed they were God's people by virtue of the fact that God made a covenant with Israel. The validity of the covenant that God made with Israel depended on God's faithfulness to his covenant. Of course, since God made the covenant with Israel, he expected them to uphold the Torah. Keeping Torah

maintains one's position in the covenant, but it does not earn God's grace as such ... Righteousness in Judaism is a term which implies the maintenance of status among the group of the elect (Sanders 1977:420, 544). ${ }^{2}$

1 Campbell refers to the Finnish school of Luther interpretation, "primarily inspired by Tuomo Mannermaa", who "argues for a nontraditional center of Luther's thoughts in categories ... in relation to Christintimacy, participation, transformation ... The Finns argue vigorously that Luther's justification language and argumentation presuppose this more fundamental, intimate, participatory... stratum."

2 "With the exception of Ben Sirach ... in all the literature surveyed, obedience maintains one's position in the covenant, but it does not earn God's grace as such. It simply keeps an individual in the group which is the recipient of God's grace" (Sanders 1977:420). In other words: "obedience is universally held to be the behaviour appropriate to being in the covenant, not the means of earning God's grace" (421). Dunn 
NGTT Deel 54, Nommers $3 \& 4$, September en Desember 2013

This was an argument that had been made before by Christian scholars like G. F. Moore in the 1940s and W. D. Davies in the 1960s, but Sanders' argument was much more influential. He described first century Judaism as "covenantal nomism" - the keeping of the law (Greek: nomos) maintained the relationship that rested on God's covenant with Israel. It is not by observing the law that one entered into a covenant relationship with God - it was the opposite: God made his covenant with the people of Israel of his own choice, and then gave them the Mosaic law.

If Sander's depiction of first century Judaism was correct, this would have consequences for the interpretation of Paul. If the Judaism that Paul interacted with did not demand that people keep the Law of Moses so that they could be included in God's covenant, then why did Paul so vehemently warn against the notion that someone may be justified "by observing the law" (Gal. 2:16)? Why did he so fiercely warn against the temptation to "rely on the law and brag about your relationship to God" (Rom. 2:17), if there were not some Jewish Christians who were tempted to do just that, if there were not Jewish Christians who thought that their keeping of the law would (at least partially) justify them before God? Why did Paul so emphatically renounce the advantage of a curriculum vitae that met the requirements of the law (Phil. 3:6) if there were no Jewish Christians who were attempted to do just that?

Paul clearly did warn his readers (at least in Galatia, but also in Rome and Philippi) not to rely too much on the Law of Moses. He also warned them against abusing it. But what was the danger in relying too much on the observance of the law - if it was not a matter that some believers might be tempted to think that their observance of the law earned them favour with God? What was the misuse of the law that Paul warned his readers against?

Sanders answered this question in another influential book published in 1983, Paul, the Law, and the Jewish People. According to Sanders, when Paul criticised the law - for example, in Romans, Galatians and Philippians - he was not criticising early Christians who thought that they had to supplement their faith in Christ with good deeds - as many Roman Catholics in the sixteenth century thought. Paul was criticising those early Christians who thought and taught that to be fully part of the community of Christians, believers had to bear the "identity markers" of the law - circumcision, a kashrut diet and keeping the Sabbath. In other words, the only way for them to enter the early Christian community was through the Jewish gate - they had to become Jews first, before they could fully become Christians. Those who did not bear the "identity markers" of the law were not welcome as full members of the Christian com munity. If they were accepted, it was with certain reservations - they were, for example, excluded from full table fellowship. In Galatians 2 Paul answers the question, "Who is a member of the people of God?" with the teaching "that all who share faith in Christ belong at the same table no matter what their racial differences, as together they wait for the final new creation" (Wright 1997:122).

\section{A retranslation of "pistis Christou"}

The debate on the retranslation of pistis Christou ${ }^{3}$ concerns the question whether this phrase

(1990:335) agrees: "This covenant relationship was regulated by the law, not as a way of entering the covenant, or of gaining merit, but as the way of living within the covenant..." Dunn was, as far as we know, first to coin the phrase "the New Perspective on Paul", in a lecture in 1982 (Wax 2001:3).

3 Pistis Christou (Gal. 2:16; Phil. 3:9), or in its main variations pistis Iesou Christou (Rom. 3:22; Gal. 3:22), pistis Iesou (Rom. 3:26) pistis huiou thou theou (Gal. 2:20). Cf. Van Wyngaard (2007) for an introduction 
NGTT: Oopbron - http://ngtt.journals.ac.za

should be translated as an objective genitive - "faith in Christ" - or as a subjective genitive "faith(fullness) of Christ". Since the debate could not be settled on a pure grammatical level (Van Wyngaard 2007:4), other hermeneutical concerns influenced translations over the years. Those in Protestant circles, and the Bible translations in this tradition, normally chose to translate it as "faith in Christ" - the objective genitive - although the subjective genitive, "faithfulness of Christ", always had its few supporters. It may be fair to say that Luther's translation of the phrase as "faith in Christ" had a major influence on Protestant scholars and translators. For many of them, consciously or unconsciously influenced by Luther's theology, it seemed obvious that in Romans 3:22 pistis lesou Christou had to be translated as: "This righteousness from God comes through faith in Jesus Christ" - and not "through the faithfulness of Jesus Christ".

However, these assumptions have been challenged in the last two decades mostly by scholars from a Protestant background. Seminal in this debate was the $1981 \mathrm{PhD}$ study by Richard Hays, republished in 2002 by Eerdmans as The Faith of Jesus Christ, which is how Hays translated pistis Christou. Hays insisted that his book does not only focus on the question of right translation, but "that the discussion of this problem should be placed in the framework of a more comprehensive debate about the story shaped character of Paul's theology" (2002:xxiv). This wider debate certainly refers to the question of where the emphasis should fall: on the Christian believer's faith in Christ (as it is stressed by the Lutheran tradition) or on Christ's faithfulness to believers. Hays admits in his 2002 preface that "the great adversary whose shadow looms over The Faith of Jesus Christ is Rudolf Bultmann" (2002:xxv), who was a strong supporter of the "faith in Christ" translation and which fitted neatly into his liberal Lutheran and individualistic interpretation of Paul.

Others have followed Hays. Douglas Harink (2003:28) rejects the traditional Lutheran definition of justification in Jesus Christ as "predominantly anthropocentric" and individualistic. According to Harink (2003:41), the phrase pistis Christou should not be translated as "faith in Christ" but as "the faith(fullness) of Christ" because the dominant narrative in the gospel is the story about God's faithfulness in relation to Jesus' faithfulness (2003:41). A pattern of nonLutheran interpretation arose: Paul was not driven by his introspective guilty conscience for not fully keeping the Law of Moses (Stendahl) because his problem with the law was not that it was used by individuals to acquire God's grace through keeping as many laws as possible. Rather, Paul's criticism of the law originated from the social function of the law (Sanders and Dunn). Hence the pistis Christou that will save believers is not their "faith in Christ" but "Christ's faithfulness" to them (Hays, Harink, Wright, and others). Donfried (2007) was right when he saw this as a combined critique of the traditional "Lutheran" reading, which he felt called to defend. This pattern was supported further by a questioning of the third pillar in the traditional "Lutheran reading": a rethinking of the concept of justification.

\section{A redefining of the concept of righteousness of God}

The redefining of the concept of justification follows a process similar to the retranslation of pistis Christou. It questions the classic Lutheran understanding that describes justification by faith as the imputation of the righteousness of God on an unrighteous person, which is then received in faith by the person - a process that takes place in the individual believer. Justification - God's gift of righteousness received by faith - is imputed to the believer, thus making him or her someone who is justified by God. This is the traditional language of Protestantism. According to this understanding, the dikaiosune theou, the "righteousness of God", is an objective genitive - the righteousness which God bestows on believers.

to the grammatical aspects of the debate. 
NGTT Deel 54, Nommers $3 \& 4$, September en Desember 2013

This traditional Lutheran view is now questioned by a number of Pauline scholars. Should dikaiosune theou not be read (at least in some cases) as a subjective genitive, describing the "righteousness which belongs to God and proceeds from him" (Käsemann 1961:181)? Yes, in places Paul uses the phrase in the objective sense, for example, in Philippians 3:9, which contrasts "a righteousness of my own that comes from the law" with "the righteousness that comes from God". Also in Romans 5:17 Paul clearly speaks of "the gift of righteousness". But then there are many other passages where righteousness is not simply a gift from God that is bestowed on the individual believer, but a righteousness that is an attribute of God - and, when given to believers, it transforms the recipient of the gift. Think of Romans 1:17, which speaks of "a righteousness from God [that] is revealed"; or of Romans 5:5, where it is said that "our unrighteousness brings out God's righteousness more clearly"; or of Romans 3:25, which says that Christ died so that God could "demonstrate his righteousness".

These examples do not deter from the fact that "righteousness" is a gift to believers, but rather reminds one that this gift is not an object - it is God's righteousness that transforms one when one receives it. That is why Käsemann (in 1961 already!) could say about righteousness from God:

Die hier mitgeteilte Gabe is nicht und nie von ihren Geber ablösbar. Sie partizipiert am Character der Macht, sofern in ihr Gott selber auf den Plan tritt, und mit ihr auf dem Plane bleibt (1961:186).

God's righteousness not only forensically declares that believers are not guilty, it starts to transform them and to transfer power to them. That is why God's righteousness in Romans 1:17 and 3:21 is referred to in the language of an epiphany: God's righteousness is not simply bestowed on an individual, it is revealed for everyone to see.

This is a very important point that should not be missed, writes Käsemann. It reminds one not to think of the righteousness of God as a gift received by individuals. Paul's view of human beings is often misunderstood in such a too individualistic manner, and as a result, it is forgotten that the place where God's righteousness should be revealed includes the theatre of history. Receiving the righteousness of God is not only a solitary experience of the individual believer; it is foremost the saving act of God, a manifestation of God's eschatological glory. ${ }^{4}$

These exegetical remarks made by Käsemann in 1961 and by others helped scholars such as N. T. Wright (1997) and Harink (2003), forty years down the line, to see more clearly the consequences of God's righteousness for the wider world in which we live. ${ }^{5}$ That is why Harink could argue that, with this New Perspective on Paul, we understand that justification is best conceived in terms of "God's rectifying justice", which liberates and transforms the world and brings human beings into "a way of life that corresponds to the pattern of Jesus Christ's own faithfulness" (2003:28). Wright distinguishes this interpretation of the righteousness of God

4 "Alles Gesagte läst sich dahin zusammenfassen, dass dikaosune theou für Pauls die sich eschatologisch in Christus offenbarende Herrschaft Gottes über der Welt is ... die Gottesgerechtichkeit von Paulus [ist] nicht primär auf das Individuum bezogen...” (1961:192).

5 Wright argues that the core of Paul's gospel is not justification by faith, but the death and resurrection of Christ and his exaltation as Lord (1997:45). "Justification is the doctrine which insists that all those who have this faith belong as full members of this family, on this basis and no other" (1997:132).

“'Righteousness' thus comes to mean, more or less, 'covenant membership', with all the overtones of appropriate behaviour, e.g. Phil. 1:11” (2001:591). 
NGTT: Oopbron - http://ngtt.journals.ac.za

from Luther's interpretation. Luther corrected the medieval understanding of distributive righteousness, but "directed attention away from the biblical notion of God's covenant faithfulness and instead placed greater emphasis upon the status of the human being" (2001:591).

\section{Did LUTHER REALLY GET IT THAT WRONG?}

A lack of space does not allow for an examination of all three claims made by the New Perspective movement. Therefore, the focus will be on the first and most important issue: Was Luther (and the tradition that followed him) mistaken in his interpretation of Paul's polemic against the law? And if it is the case, should Luther's reading be discarded?

The first answer is yes. Luther's reading of the historical reasons for Paul's polemic against the law was indeed wrong. According to Luther, Paul's polemic was against (Jewish and Gentile) Christians who thought and taught that faith in Christ should be supplemented by observance of the law - just as, in Luther's own time, many Catholics believed, preached, and implied that one's faith in Christ should be supplemented by good works. See, for example, Luther's commentary on Galatians 2:4 and 16:

Now the truth of the Gospel is, that our righteousness comes by faith alone, without the works of the law. The corruption or falsehood of the Gospel is that we are justified by faith, but not without the works of the law. With this condition annexed, the false apostles preached the Gospel. Even so do our ... Papists at this day ... Yet hereupon is the whole Papacy grounded: For there is no religious person (monachus), but he hath this imagination: I am able by the observation of my holy order to deserve grace of congruence, and by the works which I do after that have received this grace ... (Luther 1953:98, 131).

This might have been true of most Catholic interpretations of the faithworks interaction in the sixteenth century, but the New Perspective is right in its claim that this was not Paul's primary concern in his correspondence with the Christians of Galatia. He was addressing the question: Who belong to the people of God as defined by God's revelation in Christ - and, therefore, who may be allowed into the communion with those who belong to the body of Christ? Who are allowed to partake of the Lord's Supper? Who have full access to possible positions of power? The reasons why proponents of the New Perspective are right regarding this issue are the following:

1. The (potentially disruptive) question of who were regarded as full members ${ }^{6}$ of the firstcentury Christian communities was a question that all these communities had to answer in some way or another.

The reason for this was simply because, in most of those communities, there were people from both Jewish and Gentile descent. Before Jesus, the rules were clear - even if they were not upheld by all: Jews and Gentiles could not share in close fellowship. They could not eat together - it was forbidden by the Law of Moses.

6 Membership should here not be misunderstood as a formal membership as in the twentyfirst century, but simply as an indication of who was regarded, by the majority members of a group, as belonging to the group. 
NGTT Deel 54, Nommers $3 \& 4$, September en Desember 2013

In any gathering that included both Gentile and Jewish Christians, the law had the potential to severely restrain intimate fellowship on an equal footing. Equal and intimate fellowship could only happen if the law was ignored. If the law was upheld, such a gathering could only function on an unequal footing: Gentiles could meet with Jews, but could not enjoy table fellowship with them.

Such gatherings were not simply hypothetical. I elsewhere argued that, in some first century Jewish communities, the category of "God-fearing Gentiles" was such a group of people who were on an unequal footing with their Jewish compatriots - they were Gentiles who worshipped the God of Israel and, because of that, they were recognised by Jewish communities as Godfearing Gentiles (Wessels 1988:114). Some "God fearers" fully converted to Judaism - they were called "proselytes" (literally: "those who went over"), which meant that they undertook to keep the law and abide by its identity markers: they were circumcised, agreed to keep a kashrut diet and observe the Sabbath. They were Gentiles who actually became Jews - and, as a result, they enjoyed full fellowship with their Jewish compatriots. "God fearers", on the other hand (irrespective whether the term was used or not), remind us of another group of Gentiles that shared the Jewish faith, people who were "religiously" Jews but, because they did not meet the requirements of the law in respect to the identity markers (circumcision, kashrut, Sabbath), they were not regarded by the Jewish community as Jews, even though it was granted that they were "God-fearing".

Nearly all early Christian communities around the Mediterranean faced this problem: Will they allow a similar pattern of two tiered "membership" (proselytes and God fearers) that existed in some Jewish communities to be replicated in the body of the Messiah? To people looking back from a Christian perspective two millennia later, the choice seems obvious - but not so to early Christian com munities, where leadership and power were more often than not in the hands of Jewish Christians. For many of the latter the obvious answer was to keep the law as identity marker, and to expect of newcomers to follow the age-old pattern. After all, Jesus came as the Jewish Messiah, as a fulfilment of Jewish prophesies.

Peter's behaviour in Antioch shows that, despite his exposure to converted Gentiles, he still followed this line and still expected the law to function as an identity marker. Paul strongly disagreed. He saw that with God's revelation in Jesus a new age had dawned, an age wherein the only identity marker of the people of God was whether someone was grafted by faith "into Christ". This is why Paul addressed this issue in his letter to the Galatians. He had learnt that other Christians suggested to the Galatians (most of whom were of Gentile origin) that they would only be true "children of Abraham" if they accepted the law as their identity marker. This is not true, Paul wrote to the Galatians. The true children of Abraham are "those who believe" (Gal. 3:7).

This issue - the interaction between Jewish and Gentile Christians - is something Paul found necessary to address in almost all his undisputed letters. In Romans $9-11$ he cautions the Gentile members of the powerful Roman Christian community that they should not be arrogant and look down upon Jewish believers, because the Gentile believers are grafted into the Jewish believers. With regard to tension arising from the practical question whether believers should eat kosher or nonkosher food, Paul cautions that this is an issue where groups should allow for difference (which implies that it cannot be a law to be applied to everyone). The guiding principle should be to do whatever builds up fellow believers "for their good" (Rom. 14 - 15) and whatever takes care of those "whose faith is weak" (Rom. 14:1) and those 
NGTT: Oopbron - http://ngtt.journals.ac.za

who have"a weak conscience" (1 Cor. 8:10-12). In Philippians 3 Paul affirms that he now regards the advantage that the law brought as expendable, and that his righteousness does not come from the law (v. 9). However, the evidence is too inconclusive to decide whether he refers to the law as an identity marker or as a system of good deeds. It is of little significance that 1 Thessalonians and Philemon do not address the issue, since both are very short documents.

However, in Colossians and Ephesians, which may be early deuteroPauline letters, ${ }^{7}$ the matter is addressed. In Colossians 2:16f. Paul warns his readers that they should "not let anyone judge you by what you eat or drink, or with regard to a religious festival, a New Moon celebration or a Sabbath day" - which are clearly Jewish identity markers. In Ephesians, the bulk of the epistle is used in an effort to persuade the readers that Christ himself is our peace, who has made the two [that is, Jew and Gentile] one and has destroyed the barrier, the dividing line of hostility, by abolishing in his flesh the law with its commandments (Eph. 2:14).

Although the Epistle to the Ephesians is formally addressed to Christians of Jewish and Gentile backgrounds, large parts of the letter focus on the Gentile Christians, to remind them that they are not second-class members of the Christian community, but full members. A consequence of God's reconciliation in Christ and of the Spirit providing access to the Father to both Jewish and Gentile Christians (Eph. 2:18) is that "you (Gentile Christians) are no longer foreigners and aliens, but fellow citizens with God's people and members of God's household." If Ephesians was a circular letter sent to many congregations, as many scholars think it was, the evidence is even stronger that one of the most crucial issues in Paul's interaction with his congregations was the message that the Mosaic law should not be allowed to socially divide Christian communities into two groups, namely a first-class Jewish and second-class Gentile group. It con firms that the first and foremost problem that the Mosaic law presented in these communities, was not the question whether an individual believer was justified by faith in Christ alone (that is, without supplementary good works), but whether the law still functioned as an identity marker for Jews - and thus placed them in a different category than Gentile Christians.

2. In the Letter to the Galatians this was clearly the issue Paul addressed. That is why Paul mentions his confrontation with Peter in Antioch in such a pivotal place in the letter. Before Paul begins his theological argument, he submits his credentials. His law free mission to the Gentiles has already been ratified fourteen years ago by none other than the Jerusalem leadership: "James, Peter and John, those reputed to be pillars" (Gal. 2:9). When Peter later deviated from this agreement, Paul had the right to repudiate him in public, which he did.

In his exegesis of Galatians, Luther clearly did not give an accurate account of this situation and of Paul's attempt to convince his implied readers. Instead, Luther (and the Lutheran tradition) read Galatians through the lens of Luther's own interaction with the Catholic Church on the issue of how the sins of Christians are removed, or put differently: how they receive God's righteousness, that is, how they are justified.

\footnotetext{
7 In light of the present debates on Paul, this assumption may have to be reviewed because it can be argued that one of the main arguments of those who argue that Paul could never have written Ephesians or Colossians, is that the ecclesial concern of these two letters do not fit well with Paul's main agenda, which (it is assumed) was justification by faith. It is no surprise that some of the most vocal exponents of this circular argument come from a Lutheran background, for example, A. Lindemann (1975).
} 


\section{Conclusion}

But does this mean that Luther's interpretation of Galatians was altogether wrong? Caution is needed in answering this question and for the following reasons:

First, the Mosaic law was used as an identity marker (to show who belonged to Israel, Abraham's children). When this practice was also used in the early Christian community, the law in effect excluded some believers from intimate fellowship on an equal footing. However, this usage of the law as an identity marker and mechanism of exclusion does not mean that the law served only as social marker. It is quite possible - and this is indeed my argument - that the use of the Mosaic law, which in a specific social situation functioned primarily as an identity marker, could also have a secondary effect (in that same social situation) on some of those people who bore the much desired identity markers contained in the law, namely to regard themselves as morally superior to those who did not. That could easily have happened. Paul's own language in Galatians 2:15 suggests this: "We who are Jews by birth and not 'Gentile sinners"' Such a superior moral attitude would be a natural development. In fact, it is difficult to believe that first century Jews were not tempted to think they were blessed with a superior moral system in the Mosaic law. It is quite natural to believe that this attitude of moral superiority led to an understanding among some Jewish Christians that, although they were sinners, they were at least more righteous than Gentile believers.

It is easy to see that in such a situation there would be pressure on Gentile Christians to up their observance of the law so that they too could become more righteous.

There is no explicit evidence that this actually happened in Galatia, but that is not the argument here. The argument is that there is enough evidence that Paul anticipated such a tendency towards moral superiority, to which he responded in his letters. I suggest that is one reason for Paul's abundant use of the terms "righteous" and "justified" in Galatians 2 and 3. There are indeed indications that Paul's critique is not only against the law as an identity marker, but also that law observant (mostly Jewish) early Christians could come to think of themselves as more righteous. Evidence of this secondary critique of the use of the law is Paul's warning in Galatians 3:21: "For if a law had been given that would impart life, then righteousness would certainly come by the law."

Second, even if that was not the case - if Paul did not issue this secondary critique on the law in Galatians - then it still does not mean that Paul's warnings in the epistle about the Mosaic law as an identity marker could not, in a later situation, be used to warn against other (but similar) misuse of the law. Let us remember what the implicit assumption was of those who wanted to keep the law as an identity marker: They wanted Gentile Christians to be circumcised, to follow a kosher diet and observe the Sabbath so that they could be seen as proper Jews, proselytes - not only as God-fearing Gentiles who did not keep the identity markers - so that they could be accepted as God's people. Implied in this assumption is that only those who belong to Israel - and who bore its identity markers - were righteous enough to be part of God's covenant people and, therefore, to enjoy intimate fellowship on an equal footing. To this assumption Paul bluntly said, No! - people become part of God's people by God's grace alone.

In another, not completely different situation 1500 years later, Luther was confronted with a situation in which ethnic boundary markers played a negligible part in deciding who could be part of the people of God - in fact, the church prided herself on her catholicity. But there were 
NGTT: Oopbron - http://ngtt.journals.ac.za

other conditions put in place which mediated (and thus could control) who could be reconciled to God and who will, therefore, be included in the people of God. To these conditions Luther said a clear, No!

The situations differed, but were the issues - that the grace of God alone decides who belongs to God and to his people - so much different? I do not think so. To me it seems that Luther's exegesis of the Mosaic law in Galatians may have been historically inaccurate, but his reading was hermeneutically valid. It was indeed an example of a legitimate merging of the interpretative horizons of author (Paul) and reader (Luther).

\section{BIBLIOGRAPHY}

Campbell D. A. 2009. The Deliverance of God. An Apocalyptic Rereading of Justification in Paul. Grand Rapids, Ml: Eerdmans.

Donfried, K. P. 2007. Paul and the Revisionists. Did Luther really get it wrong? Dialog: A Journal of theology (46), 31-40.

Dunn, J. D. G. 1990. Jesus, Paul and the Law: Studies in Mark and Galatians. London: SPCK.

Harink, D. 2003. Paul Among the Postliberals: Pauline Theology Beyond Christendom and Modernity. Grand Rapids, MI: Brazos.

Hays, R. B. 2002. The Faith of Jesus Christ. The Narrative Substructure of Galatians 3:1 - 4:11. Grand Rapids, MI: Eerdmans.

Käsemann, E. 1961. Gottesgerechtigkeit bei Paulus. Käsemann, E. Exegetische Versuche und Besinnungen Bd. 2 (1970), 181-193. Göttingen: Vandenhoeck \& Ruprecht.

Luther, M. 1953. A Commentary on St Paul's Epistle to the Galatians. A revised and completed translation based on the "Middleton" edition of the English version of 1575. Cambridge: James Clarke.

Lindemann, A. 1975. Die Aufhebung der Zeit: Geschichstverständnis und Eschatologie in Epheserbrief. Gütersloh: Gerd Mohn.

Ridderbos, H. 1971. Paulus - Ontwerp van zijn Theologie. Kampen: Kok.

Sanders, E. P. 1977. Paul and Palestinian Judaism: A Comparison of Patterns of Religion. Philadelphia, PA: Fortress.

Sanders, E. P. 1983. Paul, the Law, and the Jewish People. Philadelphia, PA: Fortress.

Smit, D. J. 2006. Neem, Lees! Hoe Ons die Bybel Hoor en Verstaan. (Take, Read! How We Hear and Understand the Bible.) Wellington: Lux Verbi.BM.

Van Wyngaard, C. 2007. The Role of Christos in Galatians 2:15-21 and its Implication for the Interpretation for the pistis Christou Formulation in Galatians 2:16. Unpublished article presented as part of MA (ancient languages), University of Pretoria, South Africa.

Wax, T. 2002. NT Wright and the New Perspective on Paul. The Presbyterian Banner, May 2002 edition, 1-20.

Wessels G. F. 1988. Early Catholicism in Colossians and Ephesians? Unpublished DTh dissertation. Stellenbosch University.

Wright, N. T. 1997. What Saint Paul Really Said. Was Paul of Tarsus the Real Founder of Christianity? Grand Rapids, MI: Eerdmans.

Wright, N. T. 2001. Jesus' Righteousness and Christian Origins. In Wright, D. F., Ferguson, S. B. and Packer, J. I. (eds.), New Dictionary of Theology. London: Intervarsity Press, 590-592.

Dr. Francois Wessels

55a Kloof Street

Gardens

Cape Town

8001

francoiswessels02@gmail.com 